Japanese Yearbook on Business History - 1999 / 16

\title{
Cement Industry Use of Railways ca. 1890-1930
}

\author{
The Case of Asano Cement
}

\author{
Keiichi WaTANABE \\ Kagoshima University
}

T IS GENERALLY held that the opening of railway lines shortens the
time it takes to transport freight and people and lowers shipping
costs, and that this in turn contributes to the growth of industries. There is no doubt that the contribution of the railways to the process of industrialization of modern Japan was large. But this does not necessarily mean that the railways were able to do anything and everything just by their very existence. The trend of research in Japan in recent years has been to treat the question of when substantial transport functions or systems were in place, rather than simply recognize the building and opening of the railways as something revolutionary. ${ }^{1}$ In other words, what researchers are now seeking is that the question of whether the railways contributed to industrialization or not be discussed in the light of more than macro data; they feel it is necessary first of all to do positive research on how the railways and industrialization were concretely linked, and on the basis of such findings to consider the role that the railways played in industrialization. ' Naosuke Takamura, ed., Meiji no sangyō hatten to shakai shihon [Industrial develop-
ment and social overhead capital in the Meiji period] (Kyoto: Minerva Shobō, 1997). 
On the other hand, in business history studies of individual industries, too, it cannot be said that analyses of their reaction to and use of the appearance of modern organs of transport such as railways have been adequate. There is a mountainous pile of research done on all kinds of industrial and business histories, but much of that pile consists of works that have focused more on explaining production or financial aspects of those industries/businesses, and comparatively few, in my opinion, are analyses of the distributive aspect. One factor that possibly explains such a research trend is the fact that, in the past, Japanese research on industrial history and on transportation history have been independent fields that have proceeded each its own way without regard for the other.

The problem is not one that can be solved overnight, but in this study I would like to shed light on how one manufacturing industry reacted to the appearance of the railways and how it used the railways to its advantage, and by doing this I would like to treat it as an example of how to approach a problem in research history. I shall take up the case of one of Japan's oldest manufacturers, a company that later would go on to take over the lion's share of cement production: Asano Cement. ${ }^{2}$

As everyone knows, the cement industry deals with heavy goods that have a weak freight-bearing capacity both in the raw material state (limestone) and in the finished state (cement). This means that certain distributive conditions have to be considered when looking for a plant site, and an improvement in distributive conditions is indispensable when developing operations in the form of an expansion of production scales. That is to say, in this industry solving problems in the area of distribution had a very intimate connection with the management of operations. Asano Cement developed into a network of factories from Hokkaidō in the north to Taiwan in the south; this study will, however, concentrate on the factories in the vicinity

2 Asano Cement's commercial name has undergone several changes. It began as Tokumei Kumiai Asano Kōjō (1884-98), then became Asano Cement Gōshi Kaisha (1898-1913), and Asano Cement Co. (1913-47). To make things simple, in this study I refer to it uniformly throughout as Asano Cement. In the wake of the measures taken to break up the zaibatsu in 1947, it took on the name Nihon Cement Co., Ltd. Not too long ago it merged with Chichibu Onoda Cement Corporation, its erstwhile rival, becoming Taiheiyō Cement Corporation, as it is now called. 
of Tokyo, the place where the company originated, and focus on the problem of procuring its raw material of limestone, a problem that was closely connected with railways. ${ }^{3}$

\section{PROCUREMENT OF RAW MATERIALS IN THE EARLY DAYS}

The history of Asano Cement goes back to April 1883, when Sōichirō Asano, a coal merchant living in Yokohama, acted on the recommendation of Eiichi Shibusawa, a leading figure in the business world in those days, and leased a government-owned cement plant located in Fukagawa in Tokyo. In July of the following year Asano was able to purchase from the government at a good price both the building and the land it was on, and the plant began operations as a fully privately managed concern. ${ }^{4}$

The equipment of the government-owned plant was taken over wholesale, and early production was carried out using the wet process in shaft kilns. This method of manufacture uses as raw material slaked lime produced from calcinated limestone. The slaked lime was procured mainly from Kuzuu, a place in Aso-gun in Tochigi Prefecture. The route to Fukagawa first of all required overland transport on horseback as far as Koina, the nearest village located near a wharf; from there it was transported by inland waterways, by way of the Watarase, Tone, Edo, and Onagi rivers. The slaked lime was sometimes also purchased from places like Tosa in Kōchi Prefecture, Iyo in Ehime Prefecture, and Mino in Gifu Prefecture. All of these places were major lime-producing areas from Edo-period times. The cement industry was one of several modern industries that had been transplanted from overseas, but as far as raw materials were concerned it grew in Japan while retaining close connections with the traditional lime manufacturing industry.

${ }^{3}$ In this study I shall not touch upon the problem of the distribution of the finished product. A pioneering analysis has been made of this problem by Yoshimitsu Imuta, "Sementogyō ni okeru kokunai shijō no keisei" [The formation of the domestic market in the cement industry], in Kindai Nihon no shōhin ryūtsū [Merchandise distribution in modern Japan], ed. Kazuo Yamaguchi and Kanji Ishii (Tokyo: University of Tokyo Press, 1986).

${ }^{4}$ Unless noted otherwise, for the history of Asano Cement I am relying on Asano Semento enkaku shi [A history of developments in Asano Cement] (Tokyo: Asano Cement Co., 1940) and Nanajūnen shi [Seventy-year history] (Tokyo: Nihon Cement Co., 1955). 
Later, in 1886-87, Asano Cement's Fukagawa Factory expanded its production equipment, and slaked lime that had been purchased from external lime producers now came to be produced in the plant's own lime kiln located within Fukagawa Factory. This move to supplying their own slaked lime was taken in order to ensure quantities and to achieve uniformity in the quality of the product; from this point on, the factory began seeking the limestone raw material it needed for producing its own slaked lime. Procurement of limestone from Kuzuu also continued, and along the same route; it was always purchased from Hyōza Yoshizawa, a lime producer based in the region.

\section{IMPROVEMENTS IN THE TRADITIONAL DISTRIBUTION ROUTES}

Once cement production quantities increased after plant facilities were expanded, Asano Cement set about improving ways to procure the raw materials. In September 1888 construction of a horse-drawn railway began between Kuzuu and Koina (the Aso Horse Railway Co.); this afforded the prospects of improvement in overland transport over the part that had perforce been done by horseback in the past (see Figure 1). ${ }^{5}$

Anticipating eventual completion of the horse-drawn railway, Asano Cement opened its own limestone mine in Kuzuu, then entered into a contract with Aso Horse Railway Co. that entrusted to that company the transport of its limestone to the Koina wharf. The main points of the contract were that:

1. Asano Cement promised to mine between 37.5 to 75 tons $(10,000 \mathrm{kan}$ to $20,000 \mathrm{kan})$ of limestone a day, and Aso Horse Railway Co. undertook to transport at least 37.5 tons a day;

2. Aso Horse Railway Co. would obtain an advance from Asano Cement of 6,000 yen, to be used to extend its line to the mine;

${ }^{5}$ For more on the matters discussed below, see K. Watanabe, "Kigyō bokkōki ni okeru chihō shōtetsudō no keiei to yusō-Aso basha tetsudō ojirei to shite" [Management and transport in a small regional railway during the period of the burgeoning of Japanese enterprises: The case of Aso Horse Railway Co.], Keieishigaku [Japan Business History Review] 31, no. 3 (1996). 


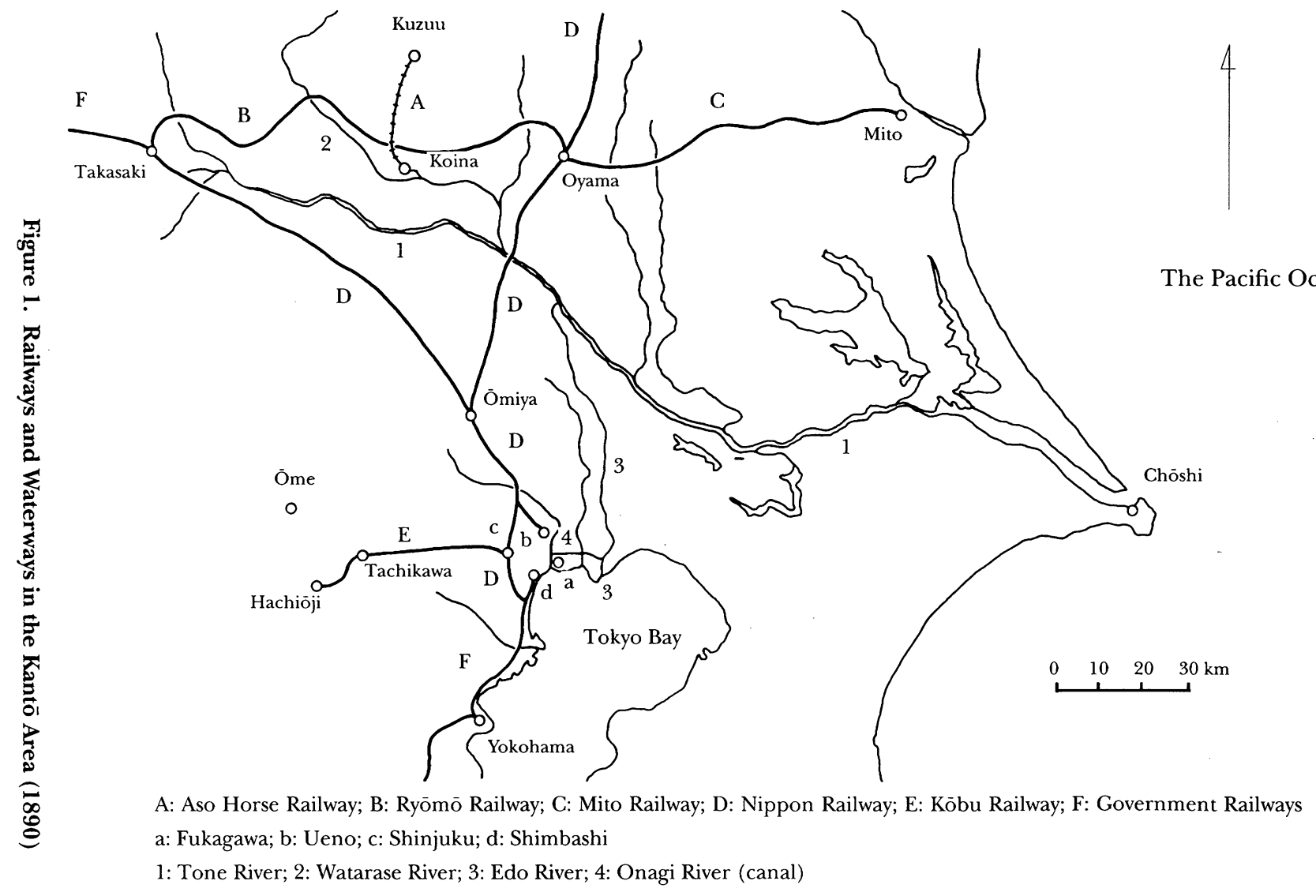


3. this advance would be repaid (without interest) within two years by Aso Horse Railway Co. subtracting one-third from the freight rates it charged Asano Cement;

4. in compensation for the "no-interest repayment" agreement, Aso Horse Railway Co. would reduce the freight rates an additional 10 percent. $^{6}$

Transport of the limestone in accord with the terms of the contract began in April 1890. It turned out, however, that, on average, the amount of limestone the horse-drawn railway was actually able to carry fell short of the amount promised. Aso Horse Railway Co. had 29 horses and 22 freight cars (as well as 4 passenger carriages), but this transport capacity was inadequate for transporting on a regular basis limestone destined for Asano Cement, on top of the normal transport of lime, timber, charcoal, etc. Furthermore, from around this time river flooding started to occur in the vicinity of Koina, the point of linkage to water transport, and the horse railway frequently was forced to suspend operations. These two factors prevented Asano Cement from attaining trouble-free procurement of its raw materials.

\section{LIMESTONE RESOURCES IN THE ŌME AREA}

The method of procuring raw materials by a combination of horseback or horse railway plus river transport was no more than the use of a distribution route that had existed from the Edo period on, or a somewhat improved version of the same. Meanwhile, however, tracks for the modern means of transportation, the steam-engine railway, were being laid all over the country, and the impact of this was making itself felt on traditional distribution routes, which began to be restructured. The effect of the new railway lines would also be felt on the methods used by Asano Cement to procure its raw materials.

Throughout the Ōme district, which is situated about 50 kilometers west of the Tokyo city area (see Figure 1), there lies an abundant deposit of good-quality limestone. In the early Edo period, limestone "for government use" was being produced in the northern part of the district (near Nariki Village) and presented to the Bakufu, but from

${ }^{6}$ Kuzuu chōsei hattatsu shi [History of the development of Kuzuu] (Ashikaga, privately printed, 1936). 
around the turn of the eighteenth century Ōme began to lose out to other producing regions like Tochigi, which had access to river transport, and from that point on the district's fortunes went downhill. After the Meiji Restoration, however, the extension of railway networks to the west of Tokyo, beginning with the construction of the Kōbu Railway in the late 1880 s, overcame the main problem behind the district's stagnation-its inaccessibility-and provided the right conditions for the revival of its limestone resources.

From 1888 plans to dig up Ōme's limestone and use railways to transport it were pushed from a quarter different from that of the Edo-period lime producers. ${ }^{7}$ The core of the group consisted of people like Hanjūrō Tamura (of Fussa Village), Mojūrō Sashida (Nishitama Village), and Tahei Ozawa (Mita Village), people who carried on sake brewing businesses and owned forests and farmland in Nishitama-gun (of which Ōme comprised the major part) in Kanagawa Prefecture, ${ }^{8}$ and even took part in regional government as members of the prefectural assembly.

At first they petitioned the Kōbu Railway to construct a branch line up to Ōme, but the petition was turned down, so they decided to go ahead and use their own resources to construct a railway, which was to be called the Ōme Railway. This does not mean that Kōbu Railway was completely uncooperative; quite the contrary, it supported the construction of the Ōme Railway and agreed to several favorable conditions, such as giving the Ōme Railway use, free of charge, of land at Tachikawa Station, which was to be the station where the two lines would meet; handling Ōme Railway's office work for them free of charge; and discounting freight charges on limestone carried out by Ōme Railway. The promoters of the scheme at first consisted only of landlords and men of wealth residing along the planned railway line, but at the time of the presentation to the government of a petition for a temporary license (in May 1891) after receiving from Kōbu Railway the aforementioned promises of cooperation, the names of central

${ }^{7}$ For more details on matters discussed in this and the next section, see my article "Ōme Tetsudō no setsuritsu to Asano Sōichirō" [The establishment of Ōme Railway and Sōichirō Asano] in Rikkyō keizaigaku kenkyū [Rikkyō economic review] 48, no. 3 (1995). Ōme Railway Co. would change its name in 1929 to Ōme Electric Railway Co., but for the sake of simplicity I refer to it throughout as Ōme Railway.

${ }^{8}$ In 1893 Nishitama-gun was transferred to the jurisdiction of Tōkyō-fu. 
industrialists and merchants were added to the petition. Included among the names of those who had joined the group of interested backers was the name of the owner of Asano Cement, Sōichirō Asano.

\section{ASANO'S MOTIVES FOR INVESTING}

One may well wonder why Sōichirō Asano put money into backing the Öme Railway. When one looks at his business activities before this, one sees that he had a history of speculative ventures aimed at "getting rich quick." Perhaps for this reason some previous representative studies have lumped him among a group of railway capitalists whose main focus of interest was the railway share market, with little or no interest in the industrial aspect of railways. ${ }^{10}$ Yet in view of the fact that investment in a small regional railway like the Ōme Railway would hardly be linked at all to an acquisition of capital gain through a rise in the value of the railway's shares, one must question the appropriateness of applying the accepted view to this particular case.

That Asano's participation in the Ōme Railway scheme was something more substantial can be inferred from the 1892 diary of Mojūrō Sashida, one of the original backers of the project. The Ōme Railway was conceived of as being at the same time both a railway company and a business operation engaged in the mining and sale of limestone, and Sashida and others made frequent visits to Asano Cement in Fukagawa in order to have talks with Asano about methods of mining limestone and other topics. The diary also records that, in response to their urging, Asano sent some of his Asano Cement staff to Ōme to inspect the lime deposits in the hills. "As we saw earlier, around this time the procurement of raw materials from Kuzuu was running into difficulties, and it can be assumed that Asano had his eyes on

9 See Kazuma Hattori, "Asano Sōichirō to Keihin kōgyō chitai no seiritsu (1)" [Sōichirō Asano and the development of the Keihin industrial belt: Part 1], in Yokohama City University's Keizai to bōeki [Industry and trade] no. 93 (1967), pp. 34-36.

${ }^{10}$ See Ken'ichi Nakanishi, Nihon shiyū tetsudō shi kenkyū-toshi kötsū no hatten to sono $k \bar{o} z \bar{o}$ [Studies of the history of private railways in Japan: The development and structure of urban transport] (Tokyo: Nihon Hyōron Shinsha, 1963), pp. 71-73.

"Sashida-ke nikki [Mojūrō Sashida's diary] (Hamura: Hamura-chō Board of Education, 1984). 
the limestone resources in Öme and on a railway company to mine it and transport it, as being one means to solve that problem.

\section{PROCURING LIMESTONE FROM THE ŌME AREA}

Ōme Railway began running trains between Tachikawa and Ōme in November 1894. In December 1895 the line reached Hinatawada (renamed Miyanohira in 1914), a place where limestone was mined. ${ }^{12}$ In that same year Asano Cement had sold its limestone diggings in Kuzuu to Hyōza Yoshizawa, its longstanding supplier, and it switched to Ōme for the lion's share of its raw material supplies. The limestone that was mined and transported by Ōme Railway Company was first transferred to the Kōbu Railway at Tachikawa Station, then carried by freight cars to Iidamachi Station in Tokyo, where it was reloaded onto barges for river transport to the factory in Fukagawa. Because the Ōme Railway had been built in the narrow gauge of 2.5 feet in an effort to save construction costs as much as possible, its freight cars were unable at this stage to be shunted directly onto Kōbu Railway's tracks, which were 3.5 feet apart.

According to a contract that is believed to have been drawn up around 1897, Asano Cement undertook to purchase 500,000 kan of limestone per month (which is equivalent to 62.5 tons per day) from Ōme Railway. ${ }^{13}$ It is difficult to make an exact comparison of transport costs, but it is estimated that Asano was paying 4.03 yen per 3.75 tons (or $1,000 \mathrm{kan}$ ) for limestone transported via the Kuzuu route (unloaded and delivered to Fukagawa Factory) around $1892,{ }^{14}$ and 5 yen for the same amount (loaded onto the barges at Iidamachi) around 1897..$^{15}$ It seems, therefore, that the main reason Asano Cement made the change of supply source was not so much cost reduction as the ability to guarantee a stable supply of limestone, and large quantities of it.

Shifting limestone procurement to Ōme meant, from the side of

12 For all the lines, stations, and mining sites mentioned in this section, see Figure 2.

${ }^{13}$ Found in a Kurebayashi family document in the possession of Ms. Chie Kurebayashi, Akishima City, Tokyo.

${ }^{14}$ According to a Sashida family document in the possession of the Hamura Municipal Museum.

${ }^{15}$ According to the Kurebayashi family document mentioned in note 13 above. 
Asano, externalization of the mining division-in other words, a return to a system of purchasing its raw materials. No documents have been found that give an account of the company's attempt at doing its own mining at Kuzuu, but there is no doubt that mining operations require a different type of labor management altogether from that needed with factory workers, and it could be that purchasing of the limestone freed the company of that burden. ${ }^{16}$

\section{ŌME RAILWAY'S INDEPENDENCE}

Asano Cement's procurement of raw materials was thus revised into something that took advantage of Ōme Railway's existence so as to link the appearance of the railways with a restructuring of its distribution network. Still, this does not, I believe, mean that Asano Cement had, right from the start, made a "backward integration" of Öme Railway. The simple reason is that neither Asano Cement nor its principals possessed a majority of the issued shares of Ōme Railway (Söichirō Asano owned only 5\%), and none of them were on that railway's board of directors (made up of the president [=managing director], ordinary directors, and auditor). Real power in management of the railway always rested with Hanjūrō Tamura, Mojūrō Sashida, and others who resided along the railway line.

Furthermore, Ōme Railway did not supply limestone only to Asano Cement; it was also filling orders from Öji Pharmaceutical Factory, Suzuki Cement Works, Ōmura Lime Factory, and others. Also, it acted on its own to develop new markets when the demand for cement was in decline-by, for example, selling the Tokyo City Hall on the idea of using limestone waste generated in the mining process in repairing roads. ${ }^{17}$ Therefore, it is difficult to maintain that Ōme Railway was subsumed under the umbrella of Asano Cement in a vertical integration type of arrangement, given the degree of independence it exercised in its management behavior. The distinguishing feature of Asano Cement's procurement of raw materials in this period was the fact

${ }^{16}$ Ōme Railway had the operations on its mining sites done by subcontractors-different ones on different sections of the sites-and the job of its own workers was to supervise the subcontracted laborers.

17 Ōme Railway Limestone Mining Division, ed., Eigyō hōkokusho [Business report], no. 9 (1899), in the possession of the Transportation Museum. 


\begin{tabular}{|ccccccc|}
\hline \multicolumn{7}{|c|}{ Table 1. Ōme Railway's Scale of Operations } \\
\& Income / Expenditure Balance
\end{tabular}

that it stayed healthy by means of a horizontal business relationship with a relatively independent regional enterprise.

The result was that the amount of limestone mined by Ōme Railway went on increasing at a stable rate. At the start of the 1900s, the profits from limestone mining would surpass those from the company's railway operations, and the mining operations remained a solid source of profits that represented an extremely high rate of return on the initial investment (see Table 1).

\section{THE INFLUENCE OF INNOVATIONS IN MANUFACTURING TECHNIQUES}

The early 1900s saw an innovation in production techniques in the cement manufacturing industry in the form of the invention of the rotary kiln. Asano Cement's Fukagawa Factory was the first company in Japan to introduce the rotary kiln, and between 1903 and 1912 it eventually built four such kilns and phased out the use of the wet process using shaft kilns.

The switch from shaft kilns to rotary kilns meant a change in the production of cement, from being an intermittent process to being a continuous one, and it signaled the establishment of a modern mass 
production system in the cement industry. Still, for the introduction of this revolutionary equipment, the setting up of a limestone supply system that could keep pace with continuous production was essential. In this respect, the 2.5-foot narrow-gauge rails of Ōme Railway, built that way in order to economize on construction costs, had the potential to become a bottleneck to procuring raw material.

In February 1907 Ōme Railway called an extraordinary general meeting of shareholders; at the meeting it decided to rebuild the tracks, this time to a 3.5-foot gauge. Widening of the tracks was completed in February of the following year; from that point on, freight cars on its line could join up directly with the main line at Tachikawa, the government-owned Chūō Line (the new name of the Kōbu Railway after the nationalization of the railways that took place in October 1906). To raise money for the costs of widening the tracks, Ōme Railway had issued new shares $(10,000)$ to a total value of 500,000 yen.

One-tenth of the shares were purchased in the name of Asano Cement. Still, Hanjūrō Tamura and the others also purchased a corresponding number of shares, with the result that the powerful shareholders in residence along the line retained their overall preeminent position. Because benefits to the region as a whole, above and beyond those of the transport of limestone destined for Asano Cement, were expected by the widening of the tracks, the local shareholders were willing to continue to put in more money for the project.

THE MARKET FOR CEMENT DURING WORLD WAR I

The outbreak of World War I provided Japan's cement industry with an opportunity for growth. Until the war the markets in Southeast Asia, in places such as the Philippines, India, and Singapore, were completely taken over by products made in Europe, but the suspension of imports from Europe during the war gave Japan's cement makers a large export market. Makers in Kyūshū and the far western part of Honshū were especially advantaged in that transportation costs from there to the Southeast Asian market were lower; they switched from sending their products to Tokyo to sending them overseas. As a 
result, the amount of cement coming into Tokyo from the outlying regions saw a sharp drop (see Table 2 on following page)..$^{18}$

The creation of a new export market and the departure of rival manufacturers from the Tokyo market would naturally work to the advantage of Asano Cement. Still, it took some while before Asano Cement would make good economic use of this great opportunity. After the war broke out, the amount of cement produced at Fukagawa Factory went up to a maximum of approximately 100,000 tons a year, but then it did not grow by much. The reason for this is that cement kiln dust had become a serious problem for the people living in the vicinity of the plant and the company was given to the end of 1916 (later extended to the end of 1917) to move its facilities elsewhere, and the company did not have the funds for additional investment in things that would lead to increased production, such as an increase in more kilns. On top of this, the construction of its Kawasaki Factory (to which the facilities were scheduled to move) was greatly delayed by the unavailability of materials created by the war and delays in the arrival of machines that had been ordered. The problem of cement kiln dust at Fukagawa was resolved towards the end of 1917 when the people living near the factory agreed to retract their demand that the factory be moved, thanks to the introduction of electrical precipitators. This left the company with two plants, one in Fukagawa and one in Kawasaki, but full-scale operations did not begin in the latter plant until 1918, towards the end of the war.

\section{BACK INTO THE LIMESTONE MINING BUSINESS}

With the cement market tending towards expansion in the wartime boom years and operations finally up and running in Kawasaki Factory, Asano Cement was feeling pressure to do something about a limestone supply system that could handle the expansion in production capacities. The company decided to add to its purchases of raw materials from the Ōme Railway by opening mines of its own to serve as sources of limestone. In 1918 new diggings were started in Chichibu

${ }_{18}$ More detailed information on trends in cement distribution as it related to the Tokyo market can be found in K. Watanabe, "Senzenki Tōkyō no semento ryūtsū" [Cement distribution in prewar Tokyo], in Kagoshima University's Keizaigaku ronsh $\bar{u}$ [Journal of economics] no. 50 (1999). 
Table 2. Amount of Cement Moved In and Out of Tokyo, by Transport Routes (in tons)

\begin{tabular}{|c|c|c|c|c|c|c|c|c|c|c|}
\hline & \multicolumn{2}{|c|}{ Moved Out } & \multicolumn{6}{|c|}{ Moved In } & & \\
\hline & Ocean & $\begin{array}{l}\text { Inland } \\
\text { Waters }\end{array}$ & Rail & Total (A) & Ocean & $\begin{array}{l}\text { Inland } \\
\text { Waters }\end{array}$ & Rail & Total (B) & $(A-B)$ & Production \\
\hline 1913 & 10,595 & 1,181 & 32,690 & 44,466 & 41,479 & 0 & 6,694 & 48,173 & $\Delta 3,707$ & 786,365 \\
\hline 1915 & 52,207 & 2,331 & 36,621 & 91,159 & 21,974 & 5 & 6,341 & 28,320 & 62,839 & 706,072 \\
\hline 1918 & 45,869 & 2,028 & 51,348 & 99,245 & 9,099 & 0 & 13,908 & 23,007 & 76,238 & $1,062,722$ \\
\hline 1922 & 5,900 & 869 & 75,405 & 82,165 & 61,108 & 0 & 28,252 & 89,360 & $\Delta 7,195$ & $1,533,917$ \\
\hline 1924 & 4,680 & 782 & 94,394 & 99,856 & 234,490 & 0 & 52,561 & 287,051 & $\Delta 187,195$ & $1,979,861$ \\
\hline 1927 & 9,273 & 737 & 53,276 & 63,286 & 301,094 & 0 & 129,954 & 431,048 & $\Delta 367,762$ & $3,256,929$ \\
\hline 1929 & 10,671 & 707 & 32,005 & 43,383 & 392,611 & 0 & 131,623 & 524,234 & $\Delta 489,851$ & $3,582,785$ \\
\hline
\end{tabular}

Sources: Annually published editions of the following: Tokyo City Hall, Tökyō-shi kamotsu shūsan chōsasho [Survey of collection and distribution of freight in Tokyo City]; Ministry of Agriculture and Commerce, Nōshōmu tōkeihyō [Statistical yearbook of the Ministry of Agriculture and Commerce]; Ministry of Commerce and Industry, Köjō tōkeihyö [Factory statistics]. 
(in Chichibu-gun in Saitama Prefecture) and Kurosawa (in Osogi Village in Nishitama-gun). ${ }^{19}$ The limestone dug up from Chichibu was transported via the Chichibu Railway and the Government Railways' Tōhoku Line and unloaded either at Sumidagawa Station or Minami-senju Station, then transported by barges to the Asano Cement plants. The Kurosawa limestone was transported via a railway line that branched off from Ōme Railway; constructed by Asano Cement funding, it was used exclusively for transporting limestone, using new freight cars ordered by the company. Thus from this time on Asano Cement would add to its character of being a process industry the character of being an extractive industry.

These moves by Asano Cement, on the other hand, also put pressure on Ōme Railway to make a further increase in its limestone mining operations. In 1918 the railway introduced new rock drills with a view to improving the efficiency of its mining operations, which till then had all been done by digging with hand tools..$^{20}$ As well, the railway also looked for a candidate to replace the mines in Hinatawada, whose deposits were nearly depleted after long years of mining there, and it began preparing a new mining site at Raiden-yama in Futamatao (in Mita Village, Nishitama-gun) and at the same time it began extending its tracks up to the new site.

\section{EXPANSION OF LIMESTONE MINING OPERATIONS}

With the end of World War I, domestic cement makers lost the special procurements for exports to Southeast Asia, so they resumed their shipments of cement to Tokyo. Cement distribution there once again resulted in an excess of available cement (Table 2). Though some of the cement being shipped in from other regions was undersold as a way to get rid of production surpluses, the demand for cement remained in an expansion mode in Tokyo. The market price stayed high even after the war; on the 8 yen per barrel (one barrel $=380$ pounds) level at the start of 1919 , the price per barrel was up to the

${ }^{19}$ Limestone mining was made possible by payment of mining fees to the president and directors of Chichibu Railway, which owned the mining rights. Chichibu Semento 50jünen $s h i$ [Fifty years of Chichibu Cement] (Tokyo: Chichibu Cement Co., 1974), p. 9.

${ }^{20}$ Öme Tetsudō sanjūnen shi [Records of 30 years of Ōme Railway] (Ōme: Ōme Railway Co., 1924), p. 63. 
level of 12 to 14 yen per barrel at the start of 1920. The use of cement for large construction projects, already common since the Meiji period, expanded even more in a construction boom, and the widespread use of cement in smaller projects such as residential construction both created an increase in domestic demand to take up the slack resulting from the downturn in exports, and provided cement makers with continued favorable conditions. During this boom Asano Cement set about adding to its facilities, so that by 1920 its Kawasaki Factory had increased production capacities by a factor of 2.5 , and the company was feverishly pursuing a policy of quantitative expansion.

Securing the limestone that was needed to back up such a policy of expansion, however, still was an unstable proposition. The Kurosawa mine that Asano had just opened in 1918 was found to have a smaller deposit than at first estimated, and it quickly became apparent that mining there would soon become impossible (and, as a matter of fact, by 1920 the mine was worked out). So the next strategy Asano Cement adopted in order to stabilize the procurement of raw materials was the decision to use Ōme Railway's extension of a line to Futamatao in 1920 as an occasion to take over from Ōme Railway the mining operations at Raiden-yama (where preparations for development were still in the preparatory stage) and also the mining operations at Hinatawada (which the railway had been running since its first years in business). The two companies concluded an agreement, the basic terms of which were:

1. for the next 25 years Asano Cement would conduct mining operations in the limestone mountains owned by Ōme Railway, and during that period the latter would receive mining fees corresponding to the amounts mined;

2 . by way of profit guarantee to the railway, a minimum shipping quota of an average of 250 tons a day was decided upon; if this quota was not met, Asano Cement would pay the railway an amount of money equivalent to the difference;

3. Asano Cement would speed up development of Raiden-yama and begin mining operations there in 1921;

4. of the limestone mined at Hinatawada, for the next five years the railway would have priority acquisition of 100 tons daily, to 
enable it to continue selling to its other long-standing customers. ${ }^{21}$

The mining fees for the Raiden-yama mine were set at 0.03 yen per ton if more than 50,000 tons were extracted over a 3-month period and 0.1 yen per ton when less than 25,000 tons were extracted over a 3-month period, while for the Hinatawada site the fees were set at a uniform 0.5 yen a ton, a figure that was comparatively high. ${ }^{22}$

Through this agreement, Ōme Railway was letting go of a limestone mining operation that was producing higher profits for it than its railway operations, but it could expect a mining fee income that would increase in proportion to the intensity with which Asano Cement went about mining and a freight income attendant upon conveyance of the limestone mined. And the actual results in 1920 far exceeded the railway's expectations. From 123,000 tons mined in 1919, the amount in 1920 soared to 205,000 tons, and subsidiary income rose from 58,000 yen in 1919 to 84,000 yen in 1920 . Income from freight charges also rose, increasing by more than 100,000 yen, and operating revenue registered a huge profit. Because the mining fees for the Miyanohira (Hinatawada) mine ${ }^{23}$ were maintained according to the terms of the agreement, even when the price of cement dropped to 6-7 yen per barrel after the severe economic recession of 1920, the giving up of its limestone mining and sales operations and the switch to reliance on mining fees and transport charges was not by any means a disadvantage to Ōme Railway. The company history that the railway published in 1924 treats the decision made at this time as if the company executives of the time were possessed of great foresight: "The executives in office then foresaw that, even though the influence of the European war would continue to present extremely favorable conditions for our country's business world in the midst of the many different disturbances, and that with all sorts of enterprises thriving the

${ }^{21}$ Ōme Railway, Eigyō hōkokusho [Business report] no. 55 (1920). While Asano Cement took over direct management of the mining operations, the actual mining was carried out under the same subcontractor arrangements as before, until 1931. See Nihon Cement Co.'s Seventy-Year History (cited in note 4 above), p. 644.

${ }^{22}$ These figures are given in an Ōme Electric Railway document in the possession of the Ōme Municipal Museum; the document is not on public exhibit.

${ }^{23}$ Since Asano Cement named the mining site at Hinatawada that it took over from Ōme Railway "the Miyanohira mine," I shall refer to it by this name from here on. 
demand for the raw material of cement, limestone, would swell, the day would come in the not too distant future when the tide would turn and the economy would be overrun by a recession. So they decided it was a better policy to look for sure figures at that point in time and aim at strengthening the foundation better, rather than make a wasteful attempt to expand operations. "'24 This assessment of the executives' foresight is, of course, second-guessing, but it is worth noting that Asano Cement did not usurp the mining operations from Ōme Railway by force, and that the railway also welcomed this step.

\section{GOING INTO RAILWAY INVESTMENT IN A BIG WAY}

Having taken over two limestone mining sites from Ōme Railway, Asano Cement was doomed to learn in 1921 that the Raiden-yama mine, which it had counted on as its main source of limestone for years to come, had smaller deposits than expected. ${ }^{25}$ The place mentioned as the next best candidate for limestone supplies was Katsubō-yama (in Ōkuno Village, Nishitama-gun), with a large deposit of good-quality limestone; the site was far south of the Öme Railway line, however. In order to get to this isolated ore deposit and be able to transport the limestone to its plants, Asano Cement embarked on large-scale investment in railway operations.

A group of local residents had founded the Itsukaichi Railway in 1919; this was to run close to Katsubō-yama, and the group had already obtained a license for the line to start out from Ōme Railway around its midpoint, at Haijima Station. Difficulties obtaining funds during the 1920 recession meant the plan was still in abeyance. Aware of the problem, Asano Cement moved at the end of 1922 to have Taijirō Asano (Sōichirō's eldest son) join the board of directors of Itsukaichi Railway, and to begin a gradual accumulation of shares in the railway company. In this way it assumed actual control of the management of the company.

${ }^{24}$ Records of 30 Years of Ōme Railway, p. 66.

${ }^{25}$ The reason for the mistaken estimates of deposits at the Kurosawa mine and then again at the Raiden-yama mine was the immature state of survey techniques used until the 1920s to explore for lime deposits in Japan; these techniques could not cope with the thick surface soil, which was also covered with many trees. See Seventy-Year History, p. 629 . 
Asano Cement also turned its attention to the Nambu Railway, which had obtained a license to build a line linking Tachikawa (Ōme Railway's starting point) and Kawasaki, and, with a view to shortening the transportation of limestone to Kawasaki Factory, it controlled the management of that railway company, too. ${ }^{26}$ The plan for the Nambu Railway was another case of a scheme that was hatched during the boom that followed World War I, but that lay abandoned because of the business problems arising from the 1920 recession. To get the plan moving again, in the middle of 1923, the year of the Great Kantō Earthquake, a group of Asano Cement's directors (Taijirō Asano, Kiyota Kaneko, and others) were appointed to the board of directors of this Nambu Railway, and simultaneously they moved quickly to gain control of the shares of the company (at the time approximately $40 \%$ of total shares). Unlike Ōme Railway, these two railway companies, because officials of Asano Cement were directly appointed to such offices as directors and because they possessed large numbers of the companies' issued shares, came to be placed in a situation in which they could be called "direct-affiliate railways" that had been subjected to backward integration by Asano Cement.

\section{THE EFFECTS OF THE GREAT KANTŌ EARTHQUAKE}

The Great Kantō Earthquake of 1 September 1923 and the period of recovery that followed brought about a new epoch in the history of raw material procurement by Asano Cement. The equipment at both the Fukagawa and Kawasaki factories suffered extensive damage from either the earthquake itself or the fires that broke out after the earthquake, but the company knew that there would be a demand for cement when rebuilding began, and so it sped up its own recovery and managed to get the plants back into production within a month to six months after the earthquake. The building of the two railways that the company controlled was pushed forward with great haste; in addition, the company obtained a license in February 1924 for

${ }^{26}$ For more on the relationship between Asano Cement and Nambu Railway, see K. Watanabe, "Nambu Tetsudō no seiritsu to Asano Semento" [The emergence of Nambu Railway and Asano Cement] in Yokohama no kindai-toshi no keisei to tenkai [Yokohama's modern age: Formation and development of the city], ed. Yokohama Archives of History/Yokohama Kindai-shi Kenkyūkai (Tokyo: Nihon Keizai Hyōronsha, 1997). 
Itsukaichi Railway to construct a separate line directly linking Haijima and Tachikawa. The reason the company gave for this was "the appropriateness of planning measures for direct conveyance by both railways, which would have the same tendencies in their freight and in their routes, so that for the sake of best use of their potentials they can rely on each other and help each other." ${ }^{27}$ What this meant was that Asano Cement planned to carry limestone from the mines to its plants using only its own "direct-affiliate railways" (see Figure 2).

The cement market in the whole of the Kantō area after the earthquake, however, especially in Tokyo, was plunged into a previously unparalleled state of fierce competition even before Asano Cement's preparations could be completed. Manufacturers all over the country, foreseeing cement would be in high demand for the reconstruction of the city, had increased their output, and cement came flooding into Tokyo by sea routes and land routes, with the result that there were 100,000 more tons of cement in 1924 than there were in 1923 , producing a surplus of 187,195 tons (Table 2 ). The manufacturers in western Japan in particular had reacted quickly and were bringing cement in by marine transport soon after news of the earthquake spread. But planning for full-scale recovery was slow, and the large demand that industry circles had been expecting did not eventuate. Imported products were also circulating since the government had temporarily removed import tariffs on cement.

Both of these factors worked together to produce a glut of cement in the market. Then some of the small makers that had sent their products to the capital despite the lack of firm prospects for sales and who were threatened by the standstill began to undersell their products. The price of cement, which had stood at 9 yen per barrel in October 1923, right after the earthquake, fell to 7 yen in July 1924, then down to 5.7 yen in September. In these circumstances the makers came to an agreement to curtail their production; in October 1924 the Cement Association, a cartel arrangement, was formed, and it set about making adjustments to production quantities and the amounts of deliveries that could be made by all members of the Association. ${ }^{28}$

\footnotetext{
${ }^{27}$ From a document of the Ministry of Railways in the possession of the Transport Museum.

${ }^{28}$ More on the formation of the Cement Association can be found in Jurō Hashimoto, "Semento Rengōkai" [The Cement Association], in Ryō taisen kanki Nihon no karuteru
} 


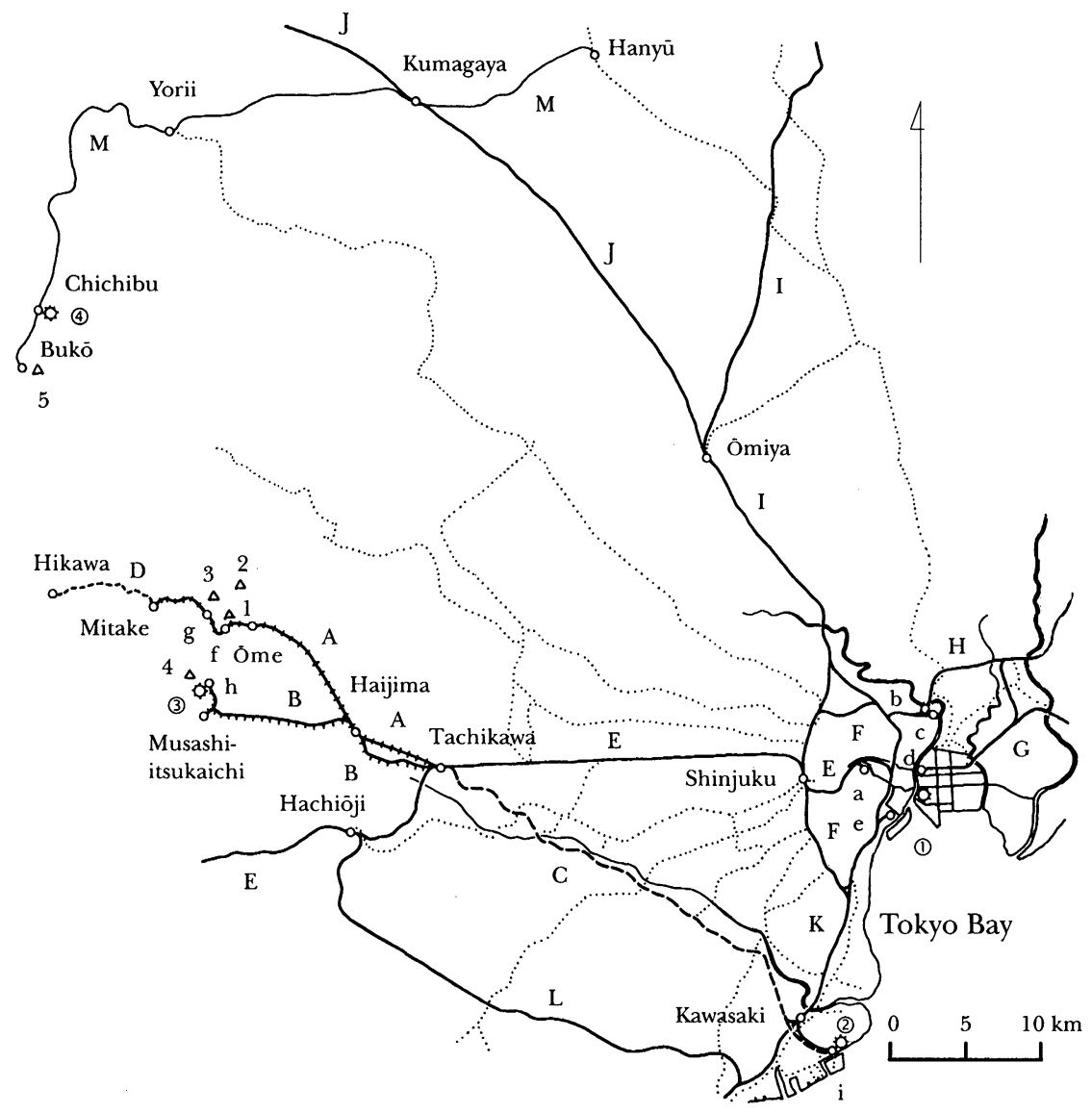

Figure 2. Asano Cement's Limestone Procuring Routes (1930)

A: Ōme (Electric) Railway; B: Itsukaichi Railway; C: Nambu Railway; D: Okutama Electric Railway (uncompleted); E: Chūō Line (GR); F: Yamanote Line (GR); G: Sōbu Line (GR); H: Jōban Line (GR); I: Tōhoku Line (GR); J: Takasaki Line (GR); K: Tōkaidō Line (GR); L: Yokohama Line (GR); M: Chichibu Railway

a: Iidamachi; b: Minami-senju; c: Sumidagawa; d: Ryōgoku; e: Shiodome; f: Miyanohira (Hinatawada); g: Futamatao; h: Musashi-iwai; i: Hama-kawasaki

1: Miyanohira (Hinatawada); 2: Kurosawa (closed in 1920); 3: Raiden-yama; 4: Katsubōyama; 5: Chichibu (Buko-san)

(1): Asano Cement Fukagawa Factory; (2): Asano Cement Kawasaki Factory; (3): Asano Cement Nishitama Factory; (4): Chichibu Cement 
Another problem was bothering Asano Cement at this time. A new player in the field, Chichibu Cement, began full-scale operations at a site not very far from Asano's Chichibu mine, and with Chichibu Cement's appearance on the scene one corner of Asano's mighty wall defending its cement supply empire in the Tokyo area crumbled. Chichibu Cement not only had adopted, thanks to the advantages that a latecomer in a field enjoys, several measures to rationalize production costs (for example, the installation of waste-heat utilization equipment that had been developed by earlier manufacturers, improved rotary kilns, and the use of paper bags for holding cement rather than barrels), but it also held a definite edge as regards procurement coststhe problem that had always vexed Asano Cement-because of the close proximity of its factory to the raw material.

In its first years Chichibu Cement acted as an "outsider" that declined to join other cement manufacturers in the Cement Association, but even after it did join in 1926 it was treated as an exception and did not have to abide by the limitations and restrictions on production quantities, consignment quantities, minimum prices, and plant expansion plans that other members were bound by, and it continued to practice its aggressive consignment offensive. Even after the formation of the cartel there was a continual increase in the amount of cement being brought into Tokyo by rail (see Table 2), and much of this was due to the activities of Chichibu Cement.

\section{IN PURSUIT OF LOWER RAW MATERIAL COSTS}

The post-earthquake intensification of competition and sluggishness of the market price forced cement manufacturers to seek ways to curtail manufacturing costs, especially the highest of them, the cost of procuring limestone. Asano Cement's first reaction was to speed up the opening of the mine at Katsubō-yama, which, because the deposits were closer to the surface, it was thought would be comparatively cheaper to mine, and the opening of Itsukaichi Railway, which would be used to carry away the limestone mined at Katsubō-yama. Ōme Railway, whose business was so set up that it depended on the income from

[Cartels in Japan between the two world wars], ed. Jurō Hashimoto and Haruhito Takeda (Tokyo: Ochanomizu Shobō, 1985). 
mining fees and from freight charges on the output from the Miyanohira and Raiden-yama mines, sensed danger ahead, and it applied pressure on Asano Cement to have the limestone mined at Katsubōyama also be shipped from Haijima to Tachikawa on Ōme's line. But, with Asano holding the trump card in the form of a possible extension of the rival Itsukaichi Railway to Tachikawa, Ōme was in no position to dictate terms, and though in the end it was able to get a promise that the limestone would be transported between Haijima and Tachikawa by Ōme Railway, it was forced, because of several circumstances that arose in the process of negotiations, to give a huge discount on the freight charges: 0.26 yen per ton (as opposed to normal freight charges of 0.4 yen a ton).$^{29}$ In 1925 the Haijima-Musashiiwai section of the railway was opened, and transport of limestone from Katsubō-yama began, but as far as Asano Cement was concerned, a reduction in transport costs had already been achieved without waiting for the completion of the entire Itsukaichi Railway line.

Asano Cement also conducted negotiations with Ōme Railway in regard to its agreements on mining fees at already established limestone mines and consignment freight charges, asking for even more reductions. For example, the mining fees that it was paying to Ōme Railway for Miyanohira had been, as mentioned earlier, set at the comparatively high rate of 0.5 yen per ton, but after successive rounds of negotiations to get them lowered, they were lowered to 0.25 yen in 1927 , then to 0.1 yen by the end of that same year, and finally down as far as 0.05 yen per ton in 1930. The freight charges for the Miyanohira-Tachikawa section also were reduced, from 0.7 yen per ton in 1928 , to 0.65 yen in $1929,0.575$ yen in 1930 , and down even farther, to 0.475 yen, by the end of $19300^{30}$

THE ROLE PLAYED BY "DIRECT-AFFILIATE RAILWAYS"

What is worth noticing in the above process of realizing reductions in mining fees and freight charges is the way Asano Cement used its

${ }^{29}$ See the Ōme Electric Railway document mentioned in note 22 above.

${ }^{30}$ Ibid. Asano Cement conducted the same negotiations for price reductions with the Chichibu Railway in regard to freight charges on the limestone mined at the Chichibu mine. 
"direct-affiliate railways" as bargaining tools in its negotiations. For example, at the time of its negotiations at the end of 1926 for reductions in mining fees for the Miyanohira mine, the director of Asano Cement's Kawasaki Factory sent a letter to the manager of Ōme Railway in which he had this to say:

In the present business climate, the level of cost of producing our goods is greatly affected by the price of the principal raw material used. At a time like this, in order to lower the cost of production on the basis of a spirit of mutual compromise, the only thing possible is for you to lower the mining fees for Miyanohira. If such an agreement cannot be reached, the president [Sōichirō Asano] would move to concentrate exclusively on Katsubō-yama. If this were to eventuate, your company not only would lose mining fees but also would face a different prospect from what was expected in regard to freight transport charges, and this would pose a considerable problem for your company. ${ }^{31}$

In other words, Asano Cement was hinting at the possibility of shifting all its limestone transport to the Katsubō-yama route, which was now possible because of the opening of the Itsukaichi Railway; at the same time it was pointing out to Ōme Railway the disadvantages that would attend the cessation of their long-standing business relationship as a result of such a shift and putting Ōme into a situation in which it, Ōme, was really unable to refuse Asano Cement's demands.

Going even further, in 1927 Asano Cement brought before Ōme Railway a plan for the establishment of an Okutama Electric Railway that would construct what would represent an extension of the Ōme line, a line between Mitake and Hikawa, and in 1928 the license for this new railway was obtained from the government. ${ }^{32}$ By the construction of the Okutama Electric Railway limestone resources even farther in

31 Ibid.

${ }^{32}$ See the Railway Ministry document referred to in note 27 above. Okutama Electric Railway's top promoter was Tahei Ozawa, Jr., president of Ōme Railway, but the other eight signatories to the application were all top officials from Asano Cement, headed by Sōichirō Asano himself. It was a company that was under the complete control of Asano, as can be seen from the exchange of a memorandum in which Asano Cement agrees to provide 2,500,000 yen of the capital funds of 3 million yen. The completion of the Okutama Electric Railway was delayed by economic recession and construction difficulties, and it did not begin operations until 1944, during World War II, when it was nationalized in order to provide wartime transport. 
the mountains could be developed and Ōme Railway could expect an increase in the freight passing over the Öme lines-this was the argument Asano Cement put to Ōme Railway when negotiating with it after the application for a license for Okutama Electric Railway was submitted, at a time when Asano was asking Ōme Railway to promise in advance a large-scale discount in freight charges covering all of Ōme's lines. This is but another instance in which we can see Asano Cement using its "direct-affiliate railways" as a bargaining tool to obtain reductions in costs on existing routes, even before the effects of opening a new line could be questioned.

Ōme Railway's business conditions deteriorated rapidly after 1927 (see Table 1). The revenue items that showed a huge fall from previous times were the incomes from limestone and from freight charges on its transport, and it was clear that this was the result of negotiations with Asano Cement over reductions in mining fees and freight charges.

It must be added in passing here that, parallel with this series of backward strategies, Asano Cement also embarked on another way to achieve its goal of reducing to a minimum its raw material procurement costs. This was to copy its rival Chichibu Cement and construct a plant located near the raw material site. Construction of a plant adjoining the Katsubō-yama mine began in 1928, and in 1929 Nishitama Factory began production and shipments. The business strategy of trying to eliminate, through improvement of distribution conditions, the distance between the plant and the limestone mining site, which Asano Cement had been pursuing through several different stages right from its beginning, and which was achieved through the new alternative of building a plant at the site where the raw materials were mined, would reach a turning point just before the world entered the big depression of the 1930 s.

\section{CONCLUSION}

In general, when one considers the relation between enterprise management and distribution, it is possible to discover two possible aspects. The first would be seen when externally existing distribution conditions and their changes have an influence on an enterprise's managerial conduct, so that the enterprise is seen as having a "pas- 
sive response." The other, on the contrary, would be seen when the enterprise's managerial strategies change the external distribution conditions and form new ways to move things, so that the enterprise in this case is seen as having an "active response."

The case of Asano Cement that we have studied in this paper represents a history of movement from the first type of response to the second. In the early years of its operations, Asano Cement's approach to the procurement of limestone, one of the most important problems to solve in the running of a cement business, was a passive one that took for granted the traditional distribution conditions, but the installation of modern distribution conditions in step with the development of railways, the increased demand for cement at the time of World War I, the intensification of competition among cement producers after the Great Kantō Earthquake-these and other watersheds in its history saw active strategies for raw material procurement become progressively more solidly entrenched in the company's approach. At first the strategy was the crude one of quantitative expansionism, but later, especially when the market price of cement was sluggish after the earthquake, the company woke up to the cost factor. Again, in its mining operations and its transport operations before World War I could be found a relation of horizontal dealings between it and an independent regional enterprise, and it was not until the 1920s at least that backward integration involving a capital-control type of stratification would make headway. The "direct-affiliate railways" that Asano Cement acquired either by inheriting the already-obtained license of a company that could not raise sufficient funds or by making new plans of its own were obviously expected to function as means to transport raw materials from newly developed areas and to shrink the distances to the plants, but at times the very plans for such railways were used to advantage in negotiations to reduce mining fees and freight charges, as was done, as we saw, with Ōme Railway. Meanwhile, construction of a plant in close proximity to a limestone mining site began at the end of the 1920s, and the backward integration strategy at Asano Cement would then reach a new stage.

* This study is based on a paper presented at the 17 July 1999 Conference of the Kantō Branch of the Business History Society held at Gakushüin University on the general theme "Enterprises and Business Logistics in 
Prewar Japan." It is also a portion of the "Senzenki Nihon no kōgyōka to yusō mondai" [Industrialization and transport problems in prewar Japan], research funded by a grant-in-aid for scientific research, 1997-98 (No. 09730053). 